\title{
Synthesis and Structural Investigation of Nano-Sized Cadmium Ferrite
}

\author{
Rakesh M. Shedam ${ }^{1}$, Ashok B. Gadkari ${ }^{1}$, Shridhar N. Mathad ${ }^{* 2}$, Mahadev R. Shedam ${ }^{3}$ \\ ${ }^{1}$ Department of Physics, GKG college, Kolhapur 416 012, India \\ ${ }^{2}$ K.L.E. Institute of technology, Hubli 580030, India. \\ ${ }^{3}$ The New College, Kolhapur 416 012, India. \\ * Corresponding author email: physicssiddu@gmail.com
}

Received: 17 September 2016 / Revised: 04 October 2016 / Accepted: 06 October 2016 / Published: 08 October 2016

\begin{abstract}
This report presents the synthesis of cadmium ferrite $\left(\mathrm{CdFe}_{2} \mathrm{O}_{4}\right)$ by Oxalate co-precipitation and its subsequent characterization by using X-ray diffraction (XRD) and Fourier transform infrared spectroscopy (FTIR) techniques. XRD results confirm the single cubic spinel phase formation with lattice parameter $8.7561 \mathrm{~A}^{\circ}$. An infrared spectroscopy study shows the presence of main two absorption bands indicating the presence of tetrahedral and octahedral group complexes, respectively, within the spinel lattice. We also report strain $(\psi)$, hopping length $\left(\mathrm{L}_{\mathrm{A}}\right.$ and $\left.\mathrm{L}_{\mathrm{B}}\right)$ and dislocation density $\left(\rho_{\mathrm{D}}\right)$ of ferrite sample.
\end{abstract}

Keyword: Cadmium ferrite, $\mathrm{CdFe}_{2} \mathrm{O}_{4}$, XRD, Dislocation density, Strain, SEM.

\section{Introduction}

Ferrites are ferromagnetic substances, with spinel crystalline structure of commercial importance due to their high frequency applications in different devices such as radio frequency coils, transformer cores etc. and thus many magnetic materials are replaced by the conventional magnetic materials [1]. Soft magnetic ferrites are used as low frequency inductors, antenna rods and wide-band and for high frequency electronic devices such as electromagnetic wave absorbers or inductor devices, due to initial permittivity in high frequency. Ferrimagnets having low RF loss are used in passive microwave components such as isolators, circulators, phase shifters, and miniature antennas operating in a wide range of frequencies (1-100 GHz) and as magnetic recording media owing to their novel physical properties [1-8].Ferrite powder, one of the very important ferrite materials has been considered for many applications such as high density magnetic storage media, MRI contrast agent, colour imaging, ferro-fluids, high frequency devices, magnetic refrigerators, catalysts, humidity sensors, gas sensor, magnetic-fludies, photo-magnetic materials, site-specific drug delivery and microwave device[8-10].Due to the unparalleled physical and chemical properties, synthesis and applications of nano-particles are focused in the research. Materials are very attractive perspective of their scientific and technological importance. Several methods like solid state method [11], auto-combustion [10], sucrose precursor [12], organic gel-thermal decomposition [13], combustion method [14], self-propagating method [15], co-precipitation [16,17], hydrothermal [18], micro-emulsion [19], thermolysis [20], and wet chemical co precipitation technique [21] are employed to synthesis the materials. The present work aimed at the synthesis and detailed structural and morphological properties of cadmium ferrites $\left(\mathrm{CdFe}_{2} \mathrm{O}_{4}\right)$ by Oxalate co-precipitation. We have 
Synthesis and Structural Investigation of Nano-Sized Cadmium Ferrite

investigated the basic structural parameters like particle size, grain size, absorption bands, strain $(\psi)$ and dislocation density $\left(\rho_{D}\right)$ of ferrite sample.

\section{Materials and Methods}

All the starting materials $\mathrm{CdSO}_{4} 7 \mathrm{H}_{2} \mathrm{O}$ (purity $99.99 \%$, Sd fine) and $\mathrm{FeSO}_{4} 7 \mathrm{H}_{2} \mathrm{O}$ (purity $99.5 \%$, Thomas Baker) were of analytical grade is used to synthesis the nano $\mathrm{CdFe}_{2} \mathrm{O}_{4}$ by standard oxalate co-precipitate method as shown in the Figure 1.

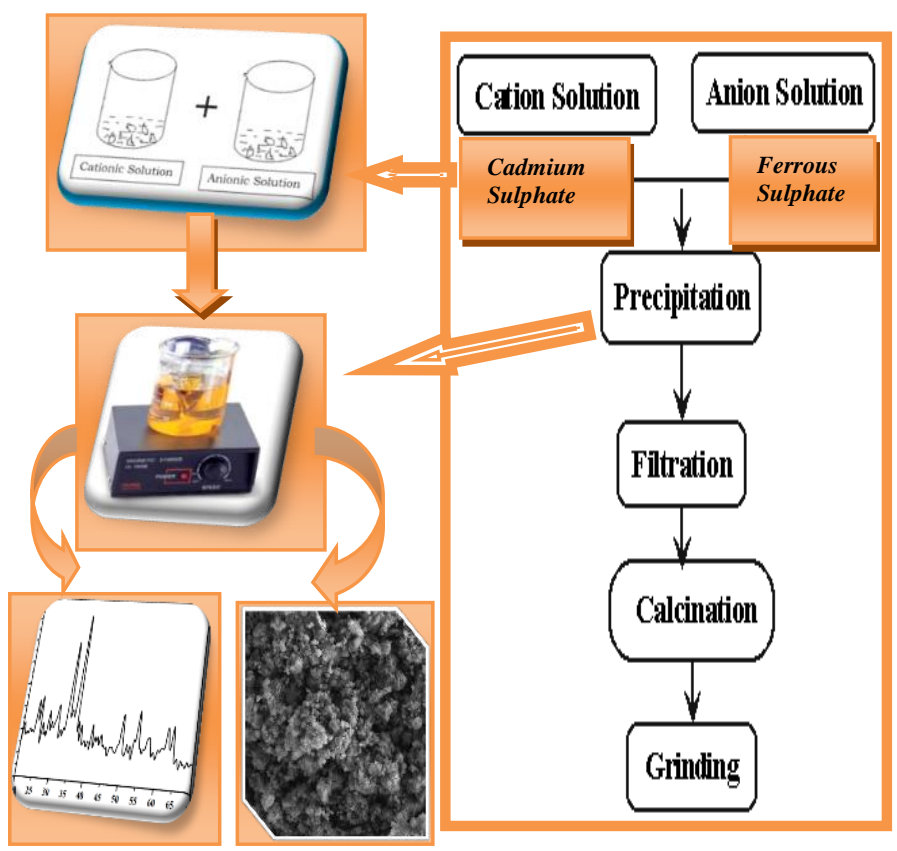

Figure 1: Schematic representation of coprecipitation route.

Filtered and dried powder is pre-sintered at $400^{\circ} \mathrm{C}$ for 5 hours and final sintering is done at $500^{\circ} \mathrm{C}$ for 4 hours. Structural characterization of the ferrite powders was carried out on Philips Diffractometer (XRD), (with $\mathrm{Cu}-\mathrm{K}_{\alpha}$ radiation, wavelength, $\lambda=1.54 \AA$ ). The scanning electron micrograph of the sample was taken on JEOL JSM 6360 SEM machine. FTIR spectra analysis carried out (using Perkin Elmer Model No. 783) in the wave numbers between $400 \mathrm{~cm}^{-1}$ and 4000 $\mathrm{cm}^{-1}$ to identify and understand the aspect of bonding in the present samples with $\mathrm{KBr}$ solvent.

\section{Results and Discussions}

\subsection{XRD Studies}

To evaluate the crystal structure of $\mathrm{CdFe}_{2} \mathrm{O}_{4}$ analysis were carried out and the XRD images of the samples are presented in Figure 2. The diffraction pattern analysis by using (220), (311), (222), (400), and (511) reflection planes confirms the cubic spinel structures.

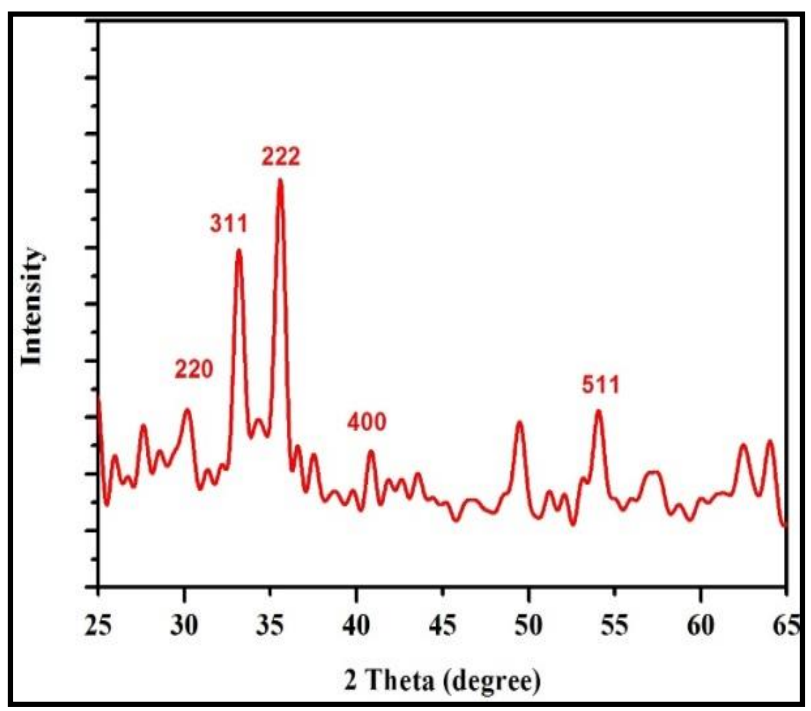

Figure 2: XRD pattern of Cd-ferrite.

Based upon Bragg's equation the condition for diffraction maxima is obtained if-

$$
\text { 2d. } \operatorname{Sin} \theta=\mathrm{n} \lambda
$$

where ' $\mathrm{d}$ ' is interplanar spacing, ' $\theta$ ' is the angle of diffraction, ' $\lambda$ ' is the wavelength of monochromatic $x$-rays and ' $n$ ' is the order of reflection (i.e. $n=1$ ). The peaks position and relative intensity matches with the standard cadmium ferrite $\left\{\mathrm{CdFe}_{2} \mathrm{O}_{4}\right.$ (JCPDC card 00-0221063)\}. This shows that synthesized sample belongs to space group Fd3mcubic spinel structure with lattice constant $8.7561 \mathrm{~A}^{0}$. For cubic spinel structure the interplanar distance ' $\mathrm{d}$ ', the lattice constant ' $a$ ' and the Miller indices (hkl) of reflecting planes are related by the equation.

$$
d=\frac{a}{\left(h^{2}+k^{2}+l^{2}\right)^{1 / 2}}
$$

The calculated value of 'a', 'd', and 'hkl' are tabulated in Table 1. The observed and calculated $\mathrm{d}$ values are in good agreement with for all the samples. Crystallite size (D) is a measure of the size of a coherently diffracting domain. The averaged grain size estimation can also be estimated by measuring the peak width at half length of full maxima. The average crystallite size 
Shedam et al., J. Mod. Mater.; Vol. 2, Issue 1, pp: 7-12, 2016

for the different compositions was calculated by Debye-Scherrer's formula [16].

$$
D=\frac{0.9 \cdot \lambda}{\beta \cdot \cos \theta}
$$

Table1: Miller indices and lattice parameter a

\begin{tabular}{|c|c|c|c|}
\hline $\begin{array}{c}\text { Planes } \\
\text { (hkl) }\end{array}$ & $\begin{array}{c}\text { Angle } \\
(2 \Theta)\end{array}$ & $\begin{array}{l}\text { d cal } \\
\left(\mathbf{A}^{0}\right)\end{array}$ & $\begin{array}{c}\text { Lattice } \\
\text { constant }\left(\mathrm{A}^{0}\right)\end{array}$ \\
\hline 220 & 30 & 2.9789 & 8.4256 \\
\hline 311 & 33.19 & 2.6995 & 8.9533 \\
\hline 222 & 35.53 & 2.5269 & 8.7535 \\
\hline 400 & 40.85 & 2.2093 & 8.8372 \\
\hline 511 & 54.09 & 1.6957 & 8.8109 \\
\hline \multicolumn{4}{|c|}{$\begin{array}{c}\text { Average lattice constant } \\
\qquad a=8.7561 \mathrm{~A}^{0}\end{array}$} \\
\hline
\end{tabular}

A dislocation is a crystallographic defect (irregularity) within a crystal structure, which strongly influences the properties of materials. The dislocation density $\left(\rho_{D}\right)$ is a measure of the number of dislocations in a unit volume of a crystalline material. Dislocations are onedimensional crystalline defects marking the boundary between a slipped and an unslipped region of a material [22]. This defect distorts the regular atomic array of a perfect crystal. The amount of the defects in the as deposited film was resolved by evaluating the dislocation density [21, $22]$ and the ferrite phase $\mathrm{x}$-ray density ( $\Delta \mathrm{x}$ Ferrite) is calculated by the following relation calculated by-

$$
\begin{aligned}
& \text { Dislocation density }\left(\rho_{\mathrm{D}}\right)=1 / \mathrm{D}^{2} \\
& \text { micro-strain }(\psi)=\beta \cos \theta / 4
\end{aligned}
$$

where $\rho_{\mathrm{D}}$ is dislocation density and $\mathrm{D}$ is crystallite size.

$$
\Delta x_{\text {Ferrite }}=\frac{8 M}{N a^{3}}
$$

where ' $\mathrm{M}$ ' is the molecular weight, ' $\mathrm{N}$ ' is the Avogadro's number and ' $a$ ' is the lattice constant. The calculated value of lattice parameter $(\mathrm{a}=\mathrm{b}=\mathrm{c})$, cell volume $(\mathrm{V})$, crystallite size $(\mathrm{D})$, Dislocation density $\left(\rho_{\mathrm{D}}\right)$ micro strain and $\mathrm{x}$-ray density ( $\Delta \mathrm{x}$ Ferrite) of ferrite samples are tabulated

\begin{tabular}{|c|c|c|}
\hline \multirow[t]{2}{*}{$\begin{array}{l}\text { Crystallite size } \\
\text { (nm) }\end{array}$} & $\begin{array}{l}\text { From Eqn. } \\
\text { (3) }\end{array}$ & $\begin{array}{l}\text { From } \\
\text { graph }\end{array}$ \\
\hline & 137 & 52.4 \\
\hline $\begin{array}{c}\text { Lattice constant } \\
\qquad\left(\mathrm{A}^{\circ}\right)\end{array}$ & \multicolumn{2}{|c|}{8.7561} \\
\hline Grain Size $(\mu \mathrm{m})$ & \multicolumn{2}{|c|}{0.17} \\
\hline Volume $\left(\left(\mathbf{A}^{0}\right)^{3}\right)$ & \multicolumn{2}{|c|}{671.324} \\
\hline $\begin{array}{l}\text { Dislocation } \\
\text { density }\left(\rho_{D}\right)\end{array}$ & \multicolumn{2}{|c|}{$5.293 \times 10^{15}$} \\
\hline Inhomogeneity & \multicolumn{2}{|c|}{0.013} \\
\hline \multirow[t]{2}{*}{ Strain $(\psi)\left(m^{2}\right)$} & $\begin{array}{l}\text { From Eqn. } \\
\text { (5) }\end{array}$ & $\begin{array}{c}\text { From W-H } \\
\text { graph }\end{array}$ \\
\hline & 0.0144 & 0.013 \\
\hline
\end{tabular}
in Table 2.

Table 2: Crystallite size, Lattice constant, Grain size, Volume, Dislocation density and Strain

The distance between magnetic ions (hopping length) in A site (Tetrahedral) and B site (Octahedral) were calculated by using the following relations [14] $\left(\mathrm{L}_{\mathrm{A}}\right.$ and $\left.\mathrm{L}_{\mathrm{B}}\right)$

$$
\begin{aligned}
& L_{A}=\frac{\mathrm{a} \times \sqrt{3}}{4} \\
& L_{B}=\frac{\mathrm{a} \times \sqrt{2}}{4}
\end{aligned}
$$

where a is lattice constant.

\begin{tabular}{|c|c|c|}
\hline \multirow{2}{*}{$\begin{array}{l}\text { Absorption Bands } \\
\qquad\left(\mathrm{Cm}^{-1}\right)\end{array}$} & $v_{1}$ & $\mathrm{u}_{2}$ \\
\hline & 565.1 & 425.7 \\
\hline \multirow{2}{*}{ Ionic radii $\left(\mathrm{A}^{0}\right)$} & $\mathbf{r}_{\mathrm{A}}$ & $\mathbf{r}_{\mathbf{B}}$ \\
\hline & 0.0144 & 0.013 \\
\hline \multirow{2}{*}{ Bond length $\left(\mathrm{A}^{\mathrm{o}}\right)$} & A-O & B-O \\
\hline & 1.906 & 2.026 \\
\hline \multirow{2}{*}{$\begin{array}{l}\text { Hopping length } \\
\left(\mathrm{A}^{\mathrm{o}}\right)\end{array}$} & $\mathbf{L}_{\mathbf{A}}$ & $\mathbf{L}_{\mathbf{B}}$ \\
\hline & 3.791 & 3.095 \\
\hline $\begin{array}{l}\text { X-ray Density } \\
\left(\mathrm{gm} / \mathrm{cm}^{3}\right)\left(\varrho_{\mathrm{x}}\right)\end{array}$ & \multicolumn{2}{|c|}{5.64} \\
\hline
\end{tabular}

The values of the Hopping length for tetrahedral site $\left(\mathrm{L}_{\mathrm{A}}\right)$ and octahedral site $\left(\mathrm{L}_{\mathrm{B}}\right)$ were arranged in Table 3.

Table 3: FTIR vibration bands, $x$-ray density, bond length and hopping lengths 
Synthesis and Structural Investigation of Nano-Sized Cadmium Ferrite

Non-zero slope of the Williamson-Hall plots

(Figure 3) are indicative [14] of inhomogeneous (i.e. strained) growth of the unit cell.

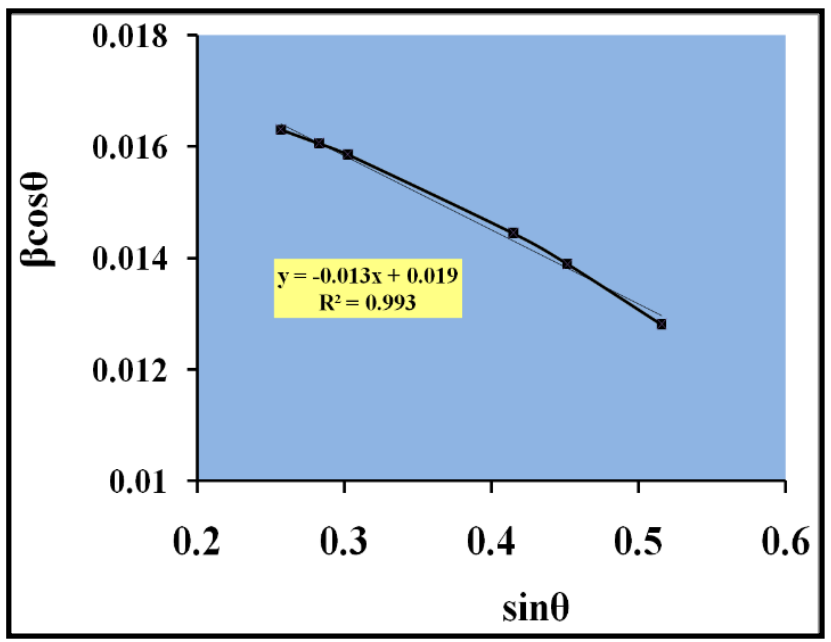

Figure 3: Plot of $\beta \cos \theta$ versus $\sin \theta$ of ferrite sample

The degree of such inhomogeneity is characterized in the last column of Table 2 . The lattice strain also was calculated using Williamson - Hall equation

$\frac{\beta \cos \theta}{\lambda}=\frac{1}{D}+\frac{\varepsilon \sin \theta}{\lambda}$

where $\varepsilon$ is Lattice micro strain, D is average crystallite size, $\lambda$ is the wavelength of $\mathrm{X}-$ Ray used, $\beta$ is the Full Width Half Maximum and $\theta$ is the Bragg's angle. The above equation is in the format $\mathrm{y}=\mathrm{mx}+\mathrm{c}$ where $\mathrm{m}=\eta$ and $\mathrm{c}=1 / \mathrm{D}$ and it is clear that by plotting the graph of $\beta \cos \theta$ versus $\sin \theta$ as gives the slope as lattice micro strain $(\varepsilon)$ and intercept as $1 / \mathrm{D}$. The graph of $\beta \cos \theta$ versus $\sin \theta$ obtained as shown in Figure3, and lattice strain $\varepsilon$ value. From the equation (3) the plot of $\beta \cos \theta$ versus $\sin \theta$ will be in the form of straight line equation giving the slope as lattice strain and also from the intercept we can calculate the effective crystallite size which is in good agreement with the value obtained from the equation (3).

\subsection{SEM Analysis}

The grain size was calculated by linear intercept method [23]. The average grain diameter $\left(\mathrm{G}_{\mathrm{a}}\right)$ was calculated by enumerating the number of grain boundaries intercepted by a measured length of a random straight line drawn on micrographs.

$$
G a=1.5 \frac{L}{M N}
$$

The scanning electron microscopy studies were undertaken for the samples images are shown in Figure 4 below.

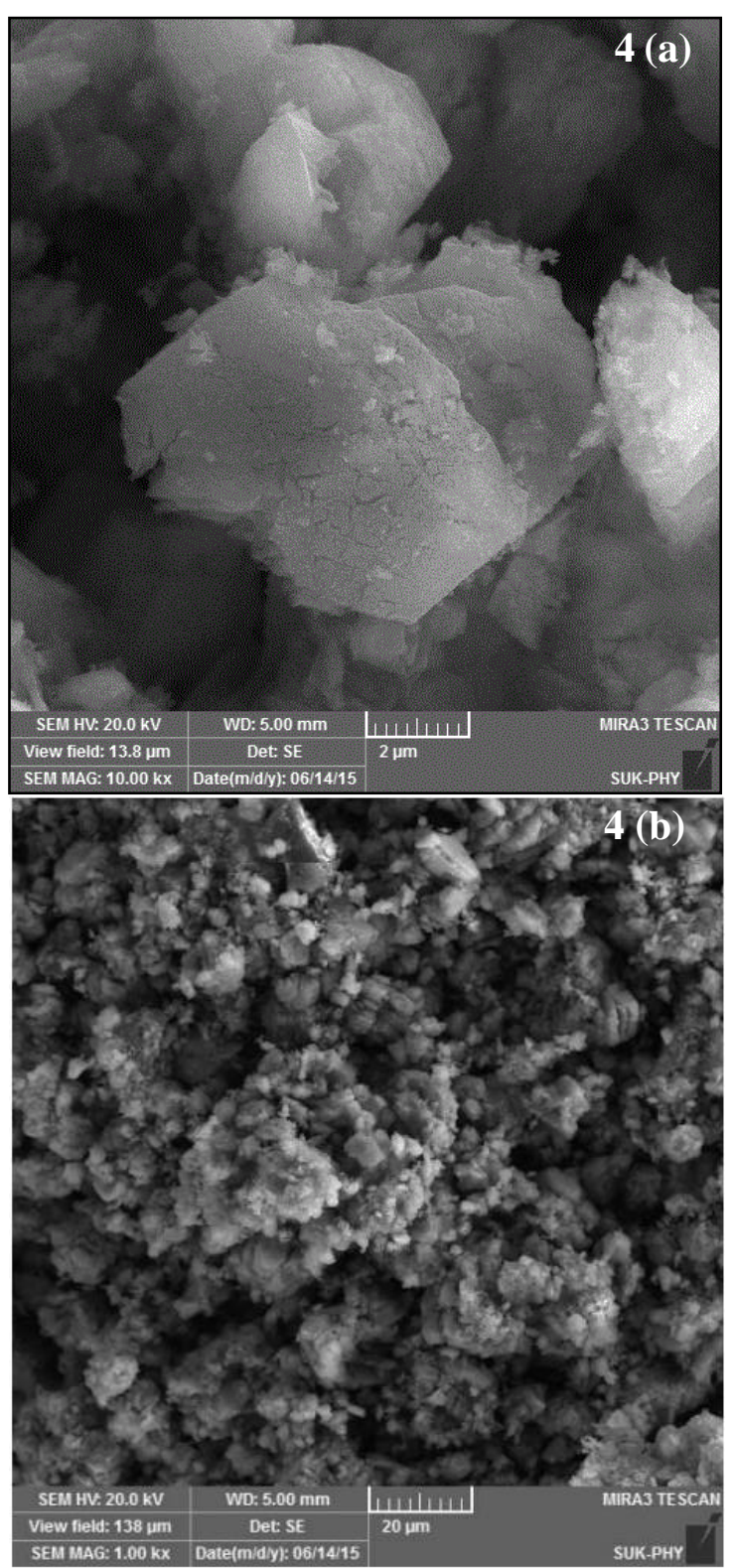

Figure 4: SEM images of Cd-ferrite. (a) $2 \mu \mathrm{m}$ (10KX magnified) (b) $20 \mu \mathrm{m}$

The average grain size is about $0.12 \mu \mathrm{m}$ with some agglomeration. It is evident from the SEM micrographs that; sample seems to be nonuniform with somewhat agglomeration in the 
synthesized samples which is unavoidable with size less than $1 \mu \mathrm{m}$. Agglomerated particle powder with inhomogeneous broader grain size distribution are Shown in Figure 4.

\subsection{FTIR Studies}

Infrared spectroscopy was used to determine the local symmetry of the solids and to study the ordering phenomenon in the ferrite samples and FTIR spectra is shown in Figure 5.

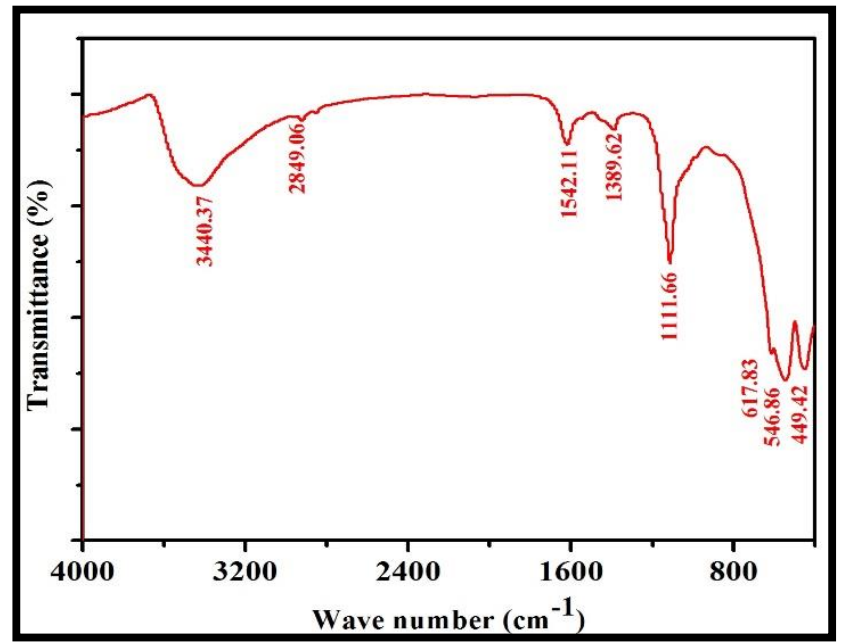

Figure 5: FTIR spectra of Cd-Ferrite

IR absorption bands mainly appear due to the vibrations of the oxygen ions with cations at various frequencies, but the spinel structure exhibits two IR vibration bands at $v_{1}=546.86$ $\mathrm{cm}^{-1}$ and atv $_{2}=449.42 \mathrm{~cm}^{-1}$ correspond to the familiar intrinsic vibrations of tetrahedral complex site and octahedral sites. The value of $v_{1}$ is more prominent than that of $v_{2}$, indicating that the normal mode of vibration of the tetrahedral complex is higher than that of the corresponding octahedral site. This may be due to the shorter bond length of the tetrahedral site than that of the octahedral site. The $v_{1}$ band is generated by stretching vibrations of the $\mathrm{Fe}^{+3}$ $\mathrm{O}^{-2}$ bond in the tetrahedral complex and the $v_{2}$ band is due to stretching vibrations of the $\mathrm{Fe}^{+3}$ $-\mathrm{O}^{-2}$ bond in the octahedral complex. Strong bands must be assigned to the vibration of the coordinated groups containing the highest valency cation $[16,24]$. The bands at $1542.11 \mathrm{~cm}^{-1}$ could be attributed to the adsorbed water (or humidity) and around $3440 \mathrm{~cm}^{-1}$ due a small amount of hydroxyl ions ( $\mathrm{OH}-)$, probably as a result of the humid atmosphere during the growth process [25-26]

\section{Conclusions}

The nano-crystalline $\mathrm{CdFe}_{2} \mathrm{O}_{4}$ successfully synthesized by Oxalate Co-Precipitation Method. The X-ray diffraction results for the samples of $\mathrm{CdFe}_{2} \mathrm{O}_{4}$ showed the formation of single phase cubic spinel structure with, having lattice constant and particle size $8.7561 \mathrm{~A}^{0}$ and $135 \mathrm{~nm}$ respectively. spinel structure exhibits two IR vibration bands at $v_{1}=546.86 \mathrm{~cm}^{-1}$ and at $v_{2}=$ $449.42 \mathrm{~cm}^{-1}$ correspond to the familiar intrinsic vibrations of tetrahedral complex site and octahedral sites. We have also discussed morphology, dislocation density $\left(\rho_{\mathrm{D}}\right)$, mechanical properties (strain), Hopping length \{tetrahedral site $\left(\mathrm{L}_{\mathrm{A}}\right)$ and octahedral site $\left.\left(\mathrm{L}_{\mathrm{B}}\right)\right\}$ of $\mathrm{Mg}$-ferrite also reported.

\section{How to Cite this Article:}

R. Shedam, A. Gadkari, S. Mathad, and M. Shedam, "Synthesis and Structural Investigation of Nano-Sized Cadmium Ferrite", $J$. Mod. Mater., vol. 2, no. 1, pp. 7-12, Oct. 2016. doi:10.21467/jmm.2.1.7-12

\section{References}

[1] R. F. Soohoo, "Theory and Application of Ferrites", Prentice-Hall, 1960

[2] Goldman, Alex, "Modern Ferrite Technology", DOI 10.1007/978-0-387-29413-1, Springer-Verlag US

[3] E.C.Snelling, "Soft Ferrites: properties and applications", Published by Iliffe Books, London (1969) ,ISBN 10: 0592027902 ISBN 13: 9780592027906

[4] R. E. Collin, "Foundations for Microwave Engineering", 2nd Ed., IEEE Press, 2000

[5] Ü. Özgür, Y. Alivov, and H. Morkoç, "Microwave Ferrites, Part 2: Passive componentsand electrical tuning", J. Mater. Sci.: Materials in Electronics, vol.20,no.10,pp.911-952 - October 2009

[6] Harris, V.G., "Advances in magnetics: Modern microwave ferrites", IEEE Trans. Magn., , vol. 48, no. 3,pp. 1075-1105, 2012

[7] B. K. Bommannavar, L. R. Naik and R. B. Pujar and B. K. Chougule, "Preparation and characterization and physical properties of $\mathrm{Mg}-\mathrm{Zn}$ ferrites, Indian Journal of Engineering and Materials Science vol.14, pp 381385,2007

[8] V.Sepelak, K. Baabe, K.Mienert, K.Schultze, F.Krumeich, F.J.Litterst, K.D.Becker, "Evolution of structure and magnetic properties with annealing temperature in nanoscale high-energy-milled nickel ferrite",J.Magn. Magn. Mater. vol.257,pp.377-386, 2003

[9] J.Zhu, D.Xiao, J.Li, X.Yang, Y.Wu, “Characterization of $\mathrm{FeNi}_{3}$ alloy in $\mathrm{Fe}-\mathrm{Ni}-\mathrm{O}$ system synthesized by citric 
acid combustion method", Scr.Mater. vol.54 (109-113. 2006

[10] S.N.Mathad , R. N. Jadhav ,R.P.Pawar , V. Puri "Electromagnetic Behavior of Lead FreeFerroelectricsat Microwave Frequencies",Advanced Science Engineering and Medicine, Vol. 5, pp. 1-7,2013

[11] M.R.Patil, M.K.Rendale, S. N.Mathad and R.B.Pujar, "Structural and IR study of $\mathrm{Ni}_{0.5-\mathrm{X}} \mathrm{Cd}_{\mathrm{X}} \mathrm{Zn}_{0.5} \mathrm{Fe}_{2} \mathrm{O}_{4}$ ", International Journal of Self-Propagating High Temperature Synthesis, , Vol. 24, No. 4, pp. 241-245, 2015

[12] M.K.Shobana, S.Sankar, "Structural, thermal and magnetic properties of $\mathrm{Ni}_{1-\mathrm{x}} \mathrm{Mn}_{\mathrm{x}} \mathrm{Fe} 2 \mathrm{O} 4$ nanoferrites" J.Magn.Magn.Mater. vol.321,no.14 2125-2128, 2009

[13] A.T.Pathan ,S.N.Mathad ,A. M. Shaikh, "Infrared Spectral studies of $\mathrm{Co} 2+$ substituted LiNi-Zn Nanostructured Ferrites", International Journal of SelfPropagating High Temperature Synthesis, Vol. 23, No. 2, pp. 112-117,2014

[14] S.M.Patange, S.E.Shirsath, S.S.Jadhv, K.S.Lohar,D.R.Mane, K.M.Jadhv, "Structural, morphological and hydrophilic properties of nanocrystalline $\mathrm{NiFe} 2 \mathrm{O} 4$ by combustion route"Mater. Lattr. vol.64 pp722-724,2010

[15] S.S.Yattinahalli, S.N.Mathad, S.B.Kapatkar, "Structural Studies of Zinc Ferrite Synthesized at Low Temperature", International Review, vol.1,no.1, pp.5-8, June 2014

[16] S.S.Yattinahalli,S.B.KapatkarS.N.Mathad, "Structural and mechanical properties of a nano ferrite", Advanced Science Focus, Vol. 2, pp. 42-46, 2014

[17] L.Guo, X.Shen, X.Meng, Y.Feng, "Effect of $\mathrm{Sm}^{3+}$ ions doping on structure and magnetic properties of nanocrystalline $\mathrm{NiFe}_{2} \mathrm{O}$ 4fibers"J.AlloyCompd, vol.490 pp.301-306,2010

[18] Sachin V. Bangale, S. R. Bamane, "Synthesis characterization and electrical properties of nanocrystallineZnMgO by combustion route" Der ChemicaSinica, vol.2,no.5,pp.22-29,2011

[19] L.Chena, H.Dai, Y.Shen, J.Bai, "Composition and film thickness effects on microstructure and magnetic properties of ordered L10-structured $\mathrm{Fe}_{100-\mathrm{x}} \mathrm{Pt}_{\mathrm{x}}$ films"J.AlloyCompod. vol.491,pp.33-38,2010

[20] N.Z.Bao, L.M.Shen, Y.H.Wang, P.Padhan, A.Gupta, "A Facile Thermolysis Route to Monodisperse Ferrite Nanocrystals", J. Am. Chem. Soc., , vol.129,no.41, pp 12374-12375, 2007

[21] Mathad, S.N. and Puri, V., Microwave studies of environmental friendly ferroelectrics, Int. Schol. Res. Notices, , vol. 2014, article ID 683986. 2014
[22] Mathad, S.N., Jadhav, R.N., Patil, N.D., and Puri, V., Structural and mechanical properties of $\mathrm{Sr}^{+2}$ doped bismuth manganite thick films, Int. J. Self-Propag. HighTemp. Synth., , vol. 22, no. 4, pp. 180-184,2013

[23] Wurst, J.C. and Nelson, J.A., "Lineal intercept technique for measuring grain size in two-phase polycrystalline ceramics"J. Am. Ceram. Soc. Bull., , vol. 55, no. 1, pp. 109-111, 1972

[24] R. Iyer, R. Desai, and R. V. Upadhyay, "Low temperature synthesis of nanosized $\mathrm{Mn}_{1-\mathrm{x}} \mathrm{Cd}_{\mathrm{x}} \mathrm{Fe}_{2} \mathrm{O}_{4}$ ferrites"Ind. J. Pure App. Phy. vol.47, pp.180185,2009 .

[25] S. Zahi, "Synthesis, "Permeability and Microstructure of the Optimal Nickel-Zinc Ferrites by Sol-Gel Route",J. Electromagnetic Analysis \& Applications, , vol.2,pp.56-62, 2010

[26] S.N.Mathad, R. N. Jadhav ,R.P.Pawar, V. Puri "Electromagnetic Behavior of Lead Free Ferroelectrics at Microwave Frequencies ",Advanced Science Engineering and Medicine, Vol. 5, pp. 1-7,2013

Publish your research article in AIJR journals$\checkmark \quad$ Online Submission and Tracking

$\checkmark$ Peer-Reviewed

$\checkmark$ Rapid decision

$\checkmark$ Immediate Publication after acceptance

$\checkmark \quad$ Articles freely available online

$\checkmark \quad$ Retain full copyright of your article.

Submit your article at journals.aijr.in

Publish your books with AIJR publisher-

$\checkmark$ Publish with ISBN and DOI.

$\checkmark$ Publish Thesis/Dissertation as Monograph.

$\checkmark$ Publish Book Monograph.

$\checkmark$ Publish Edited Volume/ Book.

$\checkmark$ Publish Conference Proceedings

$\checkmark \quad$ Retain full copyright of your books.

Submit your manuscript at books.aijr.org 